\title{
Synthesis of 2'-Modified Nucleotides*
}

\author{
Mariana Gallo $^{1, * *}$, Héctor Torres ${ }^{1}$ and Adolfo Iribarren $^{1,2}$ \\ ${ }^{1}$ Instituto de Investigación en Ingeniería Genética y Biología Molecular, UBA - CONICET. Vuelta de \\ Obligado $24902^{\circ} \mathrm{P}(1428)$. Buenos Aires, Argentine \\ E-mail: airi@proteus.dna.uba.ar \\ ${ }^{2}$ Centro de Estudios e Investigaciones. Universidad Nacional de Quilmes. Roque Saenz Pena 180 \\ (1876). Prov. Buenos Aires, Argentine
}

* This paper missed our publication deadline and was thus omitted from the Proceedings of the 12th National Symposium of Organic Chemistry (XII SINAQO), published in Molecules 2000, 5, 252-615. The Editorial Board has now decided to publish it separately in this issue.

** Author to whom correspondence should be addressed.

Received: 4 May 2000 / Accepted: 10 May 2000 / Published: 15 May 2000

\begin{abstract}
We show in this work the development of modified building blocks for the synthesis of nuclease resistant hammerhead ribozymes. These modified monomers retain the 2'$\mathrm{OH}$ which is essential for the activity of these molecules. Our final goal is to generate a catalytic antisense approach with potential application in gene therapy.
\end{abstract}

Keywords: Modified nucleotides, ribozymes.

\section{Introduction}

A ribozyme is a RNA molecule with a defined sequence and structure that recognizes and hydrolyzes a determined phosphate bond of a specific RNA sequence (substrate). Ribozymes can act in an intermolecular way (trans rupture) and they can also be designed to recognize a wide range of target sequences. Hammerhead ribozyme has been minimized to a fragment of ca. 40 nucleotides long. This structure includes the region responsible for the activity and two flanking regions which make possible the recognition of the complementary RNA sequence.

(C) 2000 by MDPI (http://www.mdpi.org). Reproduction is permitted for noncommercial purposes. 
The development of nuclease resistant ribozymes is highly desirable because of their potential application in gene therapy. They could act based on the antisense principle and additionally offer a catalytic mechanism, therefore allowing to reduce the necessary drug concentration.

Many studies have demonstrated that 2'-hydroxyls present in certain positions are essential for maintaining the hydrolytic activity of these molecules [1-2]. Due to the fact that the modifications proposed up to now lack this functional group [3-6], we have started the synthesis of the necessary building blocks to generate ribozymes with these characteristics. Furthermore, these building blocks could potentially be useful in the synthesis of ribozyme inhibitors as well as in the synthesis of other RNA sctructures where tertiary interactions are important for activity.

\section{Results and Discussion}

As shown in the scheme, the selective derivatization of the 2'-hydroxyl was achieved through the protection of 3'- and 5'-hydroxyls by formation of a disiloxane.

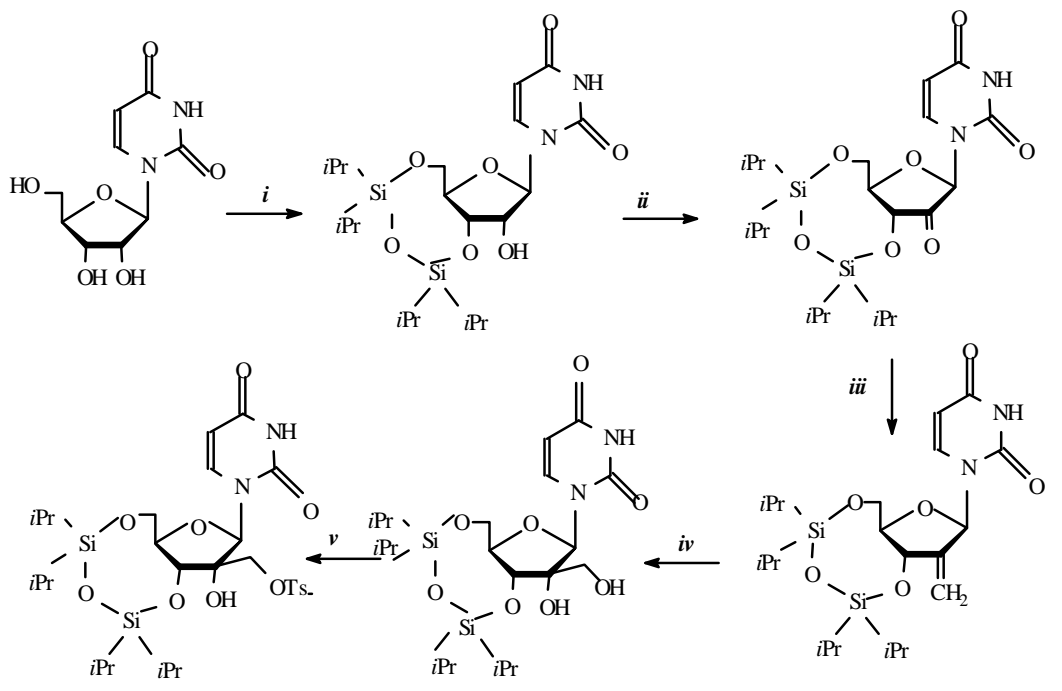

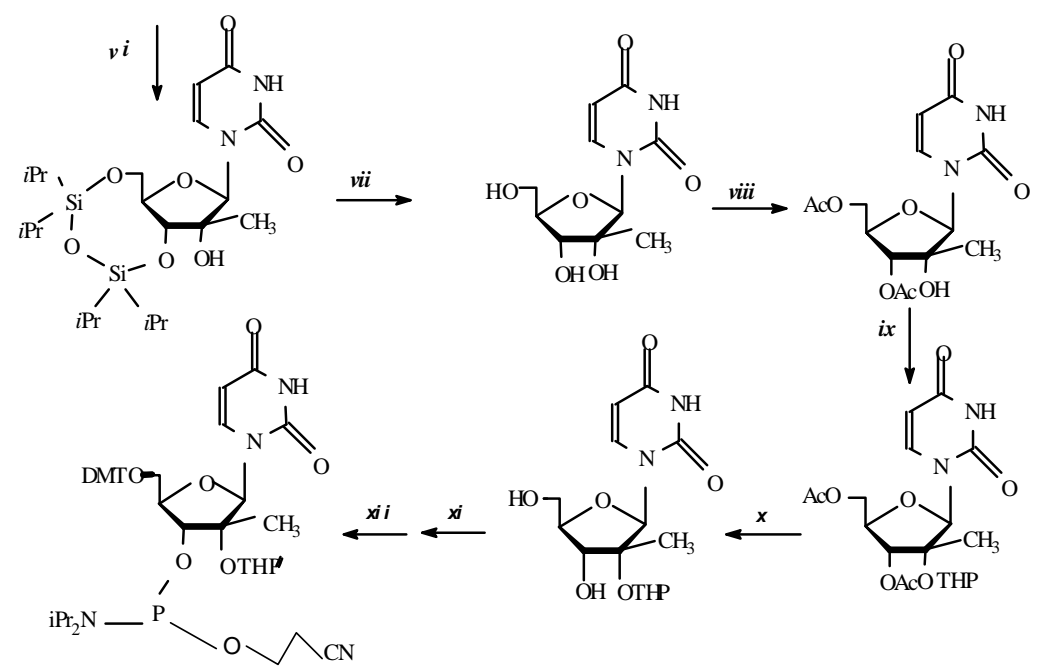

$i$ : a: TIPDSCl $2, \mathrm{Py}$; b: $\mathrm{MEOH}$ ï: $\mathrm{PCC}, \mathrm{Ac}_{2} \mathrm{O}, \mathrm{CH}_{2} \mathrm{Cl}_{2} ;$ iï: $\mathbf{a}: \mathrm{MePh}_{3} \mathrm{PBr}, \mathrm{THF} ; \mathbf{b}: \mathrm{Et}_{2} \mathrm{O}, \mathrm{NH}_{4} \mathrm{Cl}(\mathrm{aq})$; iv: a: $\mathrm{OsO}_{4}, \mathrm{~N}-\mathrm{MNO}, \mathrm{t}-\mathrm{BuOH}$ THF; b. $\mathrm{NaHSO}_{3} 1 \mathrm{M}, \mathrm{EtOAc}$; : TsCl Py; $\boldsymbol{v}: \mathbf{a :} \mathrm{NaBH}_{4}, \mathrm{DMF}$, b: $\mathrm{NH}_{4} \mathrm{O}$ (aq),vii: TBAF, THF; viii: $\mathrm{Ac}_{2} \mathrm{O}, \mathrm{Py} ; \boldsymbol{i x}$ : DHP, pTs OH, Dioxane; $x$ : $\mathrm{NH}_{3}, \mathrm{MeOH} ; \boldsymbol{x}:$ DMTrCl, DMAP, TEA, Py; $x i$ i: $i \mathrm{Pr}_{2} \mathrm{NEt}, \mathrm{CH}_{2} \mathrm{Cl}_{2},\left[\left(\mathrm{CH}_{3}\right)_{2} \mathrm{CH}\right]_{2} \mathrm{NP}(\mathrm{Cl}) \mathrm{OCH}_{2} \mathrm{CH}_{2} \mathrm{CN}$. 
The regioselective oxidation with osmiun tetroxide allowed the isolation and purification of the diol. The optimization of the 2'-hydroxyl protection was a key step. Several protecting groups were tried in order to overcome the steric problems produced by this tertiary function [1-2]. The 5'-Odimethoxytrityl group as well as the 3'-O-phosphoramidite are the necessary derivatizations required for the solid phase synthesis of the corresponding oligonucleotides.

\section{Experimental}

All the intermediates have been purified by column chromatography, affording satisfactory ${ }^{1} \mathrm{H},{ }^{13} \mathrm{C}$ and ${ }^{31} \mathrm{P}$ NMR spectra.

\section{References and Notes}

1. Pley, H.W.; Flaherty, K.M.; McKay, D.B. Nature 1994, 372, 68-74.

2. Scott, W.G.; Finch, J.T.; Klug, A. Cell 1995, 81, 991-1002.

3. Paolella, G.; Sproat, B.S.; Lamond, A.I. The EMBO Journal 1992, 11, 1913-1919.

4. Yang, J.; Usman, N.; Chartrand, P.; Cedergren, R. Biochemistry 1992, 31, 5005-5009.

5. Heidenreich, O.; Benseler, F.; Fahrenholz; Eckstein, F. J. Biol. Chem. 1994, 269, 2131-2138.

6. Beigelman, L.; McSwiggen, J.A.; Wincott, F.E.; Usman Thackray. J. Biol. Chem. 1995, 270, 25702-25708.

Samples Availability: available from the authors.

(C) 2000 by MDPI (http://www.mdpi.org). Reproduction is permitted for noncommercial purposes. 